\title{
SPATIAL EFFECT OF REFILLING DRINKING WATER DEPOTS TOWARD DIARRHEA IN PAGATAN, SUB DISTRICT OF KUSAN HILIR, TANAH BUMBU DISTRICT, SOUTH KALIMANTAN
}

\author{
Dicky Andiarsa ${ }^{1}$, Dian Eka Setyaningtyas ${ }^{1}$, Syarif Hidayat ${ }^{1}$, Ika Setianingsih ${ }^{1}$, \\ Hamsyah $^{1}$ and Erly Haryati ${ }^{1}$ \\ ${ }^{1}$ National Agency on Health Research and Development Tanah Bumbu, National Institute \\ of Health Research and Development, Indonesian Ministry of Health, Indonesia
}

\begin{abstract}
The growth of drinking water refill service business in Indonesia is one of the most promising and growing business in recent years. On the other hand, along with the conditions of diarrhea cases in this region remain concerned. This research aimed to identify spatially the influence of the existence of refilling water depots and the quality of its products to the incidence of diarrhea in Tanah Bumbu District. The study held in Kota Pagatan, sub district of Kusan Hilir District of Tanah Bumbu in November-December 2017. Water samples are taken at every depot with complete procedure and marked spatially then sample was assessed microbiologically to determined E.coli and Coliform contamination. The bacteria-positive depot on examination of the sample is categorized as 'contaminated' contrarily no bacteria depot is categorized as 'clean'. Diarrhea case data in the area of the data was taken from 2016 research data in the form of respondent data, location and household characteristics related to patient's family status and access to drinking water. Furthermore, the two types of data are integrated into spatial analysis to analyze the spatial relation of the depot's water quality with the distribution of diarrhea cases. There is a spatial suitability between the density of the depots' position and the density of the diarrheal cases found. The concentration of 'contaminated' depot has a significant effect on the characteristic profile of the most of patients who were in the vicinity of the depot.
\end{abstract}

Keywords: Diarrhea, spatial effect, drinking water access, refilling water depots

\section{Introduction}

The growth of refill drinking service business in Indonesia is one of the most promising and growing business in recent years. Each year there is a significant increase in the number of depots. Various facilities to get ready-todrink water at affordable prices become the main choice of middle-income society.(Rahmitha, Utami and Sitohang, 2018) Tanah Bumbu District itself especially Pagatan City is one of the areas that have increasing number of depots from many years ago either having license to operate as well which has no operational license.

On the other hand, diarrhea in the Pagatan region has remained high in recent years. Diarrhea data in the pagatan area is experiencing a downward trend, however the incidence of this disease is still a major public health problem in this region.(Pagatan City Health Service, 2016) A few years ago before 2010, the Pagatan area was a slum area and inadequate infrastructure. At present, infrastructure development in Pagatan has increased significantly including kampong roads and drainage so that the sanitation of the area has improved.(Kuswandi, 2017) The circumstances is in contrast to cases of diarrhea that do not show a significant reduction. 
Pathogenic agents that cause diarrhea such as coliform, Escherichia coli, Vibriospp, etc. can contaminate water and food through some carrier media such as teapots, gallons,(Wandrivel, Suharti and Lestari, 2012)even an entire refilling drinking water machine. The existence of these pathogens indicates that poor hygiene and sanitation also maintenance of equipment related to the provision of drinking water.(Rumondor, Porotu'o and Waworuntu, 2014)Data on the relation between the contaminated depots and diarrhea cases in Pagatan area is not yet available and the weakness of drinking water surveillance by the local health office is the basis of this study held.

It can be hypothesized that the growth of refill depots relates to cases of diarrhea in the Pagatan City. This paper is expected to provide input for stake holder so that the regulation can be implemented thoroughly for refill drinking water producers as well as improve the routine inspection of refill depot as a surveillance effort in maintaining drinking water quality in Pagatan City.

\section{Methods}

The study was held in Pagatan City, Subdistrict of Kusan Hilir, District of Tanah Bumbu in NovemberDecember 2017. Area of Pagatan selected because this region has the most refill drinking water depots in Kusan Hilir Sub district that is numbered 42 Depots which were successfully examined. Water samples taken at each depot after marked with Global Positioning System (GPS), water retrieval must be complete procedure in accordance with the suggested by the equipment provider then the samples were checked at the Microbiology Laboratory of National Agency of Research and Development Tanah Bumbu to determine the contamination of E. coli and coliform in water sample. The examination technique used Most Probable Number (MPN) and Total Plate Count (TPC) to calculate the amount of contamination in the sample. Selective media used are TCBS, McConkey, XLD, EMB agar and IMVIC methods. The bacteria-containing depots on examination of the sample were categorized as 'contaminated' and that no bacteria in the sample were categorized as 'clean'.

100 Diarrhea case data in the area of the field was taken from research data in 2016 (Andiarsa et al., 2016) (Andiarsa, Setianingsih and Sulasmi, 2017) in the form of respondent data, location and household characteristics related to patient's family status and access to drinking water. The data were analyzed descriptively to present the distribution of the characteristics and access of drinking water of the household of the patient by referring the $\mathrm{P}$ value to determine the significance of each variable to the diarrhea.

Furthermore, the combination of the two data is scored based on the village area or id location to determine the effect status of the depot in the area. Scores are determined based on the high, medium, or low level of cases and 'contaminated'depots in the area. The greater the number of cases and 'contaminated' depots which were we marked in red, the higher the risk of the village being exposed to diarrhea due to 'contaminated' depots which was we then refer to as effect status. Effect status score can be viewed in the following scheme: 

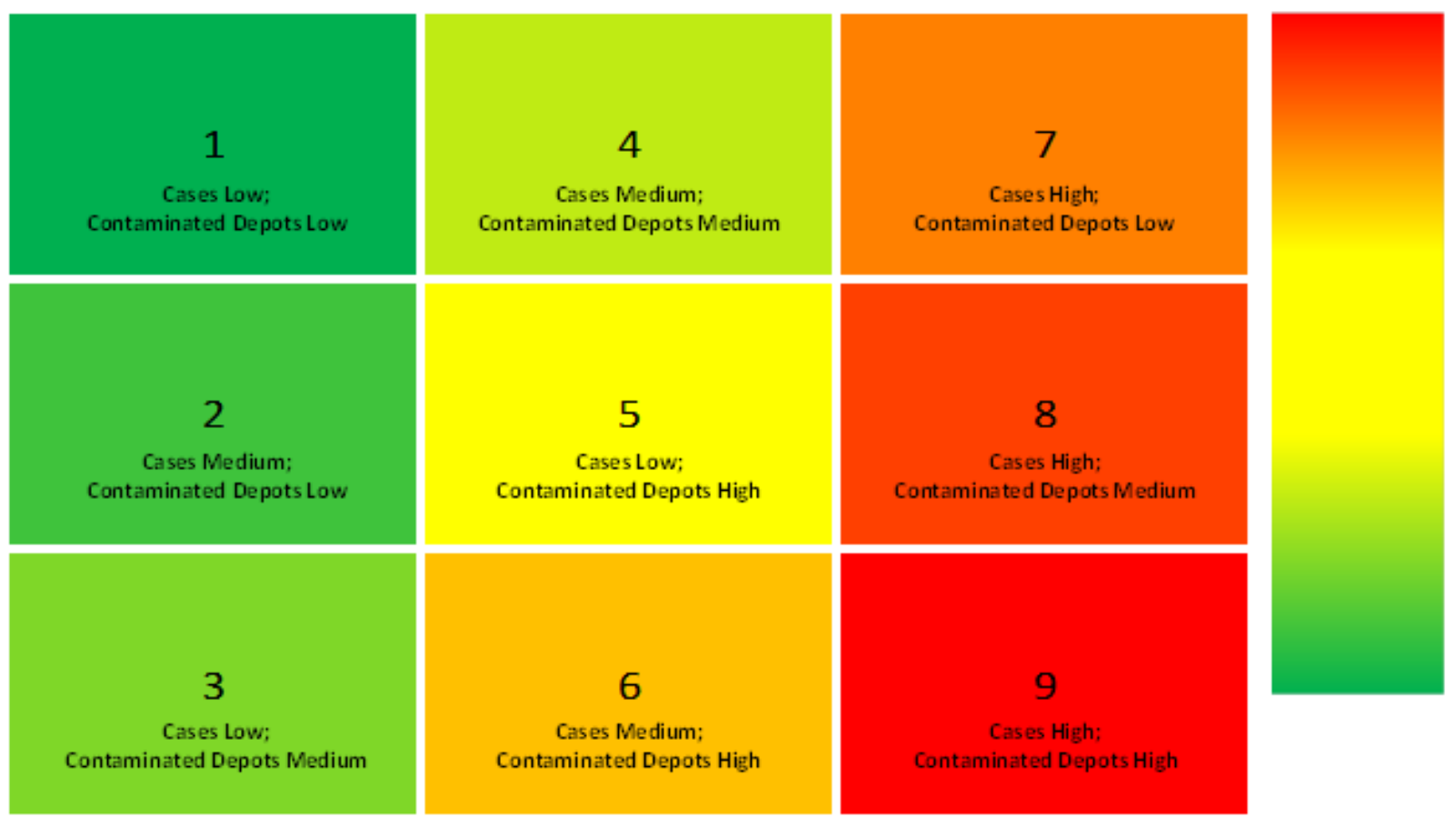

Figure 1 Effect status scoring scheme

Both types of data were integrated into spatial analysis to see the spatial linkage of the depot water quality results with the distribution of diarrhea cases. Spatial analysis was using Quantum GIS open source software application version of Nodebo $^{\mathrm{TM}}$. Spatial analysis used a simple technique of overlay and heatmap techniques. Heatmap analysis was used to determine depot concentrations and their relation to diarrhea cases. The heatmap was made at a radius of $500 \mathrm{~m}$ from the contaminated depot as the center of analysis, the more dense the number of depots in a particular area the higher the concentration and the impact that the depot may cause.

\section{Result}

Pagatan city is one of the most populous areas in Kusan Hilir Sub District with a population of 46,735 people and characteristics of the city along the coastline and several rivers close to the sea estuary. Pagatan is positioned by $3.3300^{\circ} \mathrm{S}-3.6092^{\circ} \mathrm{S}$ and $115.5900^{\circ} \mathrm{E}-115.9335^{\circ} \mathrm{E}$ with an altitude of less than 10 meters above sea level. Most of the economic activity in the region is a trade area and a small part of agriculture in the suburbs.

The results of observation and interviewed with heads of households from 100 patients in the city of Pagatan has a tendency to support diarrhea cases arisen. This shows some risk factors have a significant role to the occurrence of diarrhea in the household. Table 1 describes some characteristics of the patient and the condition of the household. The most of the work of the head of household were employees and entrepreneurs or traders who throughout the day spent at work. Most patients are in the age group 0-5 year old which were have more vulnerable than other age groups. Most households have a high density of home inhabitants, although inhabitants' density was not significant, itwas a main determinant of its impact on household health status.

Table 1 Household characteristics of diarrhea patient.

\begin{tabular}{lllll}
\hline No & Variable & & $\mathrm{N}(\%)$ & $\mathrm{P}$ \\
\hline 1 & Gender of diarrhea patient & Male & 46 & 0,905 \\
& & Female & 54 & \\
\hline 2 & Work of head of household & Employee & 25 & 0,000
\end{tabular}


Dicky Andiarsa et al / Spatial Effect Of Refilling Drinking Water......

\begin{tabular}{|c|c|c|c|c|}
\hline & & \multirow{2}{*}{$\begin{array}{l}\text { Entrepreneur } \\
\text { Farmer }\end{array}$} & \multicolumn{2}{|l|}{37} \\
\hline & & & 18 & \\
\hline & & Labour & 10 & \\
\hline & & Unemployed & 10 & \\
\hline \multirow[t]{4}{*}{3} & Age group of diarrhea patient & $0-5$ year old & 70 & 0,000 \\
\hline & & $6-15$ year old & 1 & \\
\hline & & $16-55$ year old & 23 & \\
\hline & & $>56$ year old & 6 & \\
\hline \multirow[t]{5}{*}{4} & Number of inhabitants & 2 people & 4 & 0,510 \\
\hline & & 3 people & 7 & \\
\hline & & 4 people & 27 & \\
\hline & & 5-10 people & 51 & \\
\hline & & $>10$ people & 1 & \\
\hline \multirow[t]{4}{*}{5} & Number of diarrhea patient & 1 people & 66 & 0,075 \\
\hline & & 2 people & 22 & \\
\hline & & 3 people & 11 & \\
\hline & & 4 people & 1 & \\
\hline
\end{tabular}

The availability of drinking water is determined by the ability of households to access drinking water for their household needs. Table 2 illustrates that the majority of patient households were consumers of refill drinking water depots, as access affordability and low prices and other convenience factors make the majority of households considering using refill water as their primary drinking water source. The next fact that some of these households did not retreat their drinking water such as boiling it before it is consumed also they use a water jug for storage that is kept refilled without being washed for long time period. However, the physical quality of drinking water in Pagatan area is quite good.

Table 2 Access of drinking water

\begin{tabular}{lllll}
\hline No & Variable & & $\mathrm{N}(\%)$ & $\mathrm{P}$ \\
\hline 1 & Type of drinking water & Bottled water & 3 & 0,000 \\
& & Refilled water & 68 & \\
& Local water provider & & \\
& & 23 & \\
& & (PDAM) & 1 & \\
& Drilled well & 2 & \\
& Dug well & 3 & \\
& & River & 38 & 0,000 \\
& Drinking water treatment & Boiled & 3 & \\
& & Radiation & 1 & \\
& & Filtered & 58 & 0,000 \\
& & Untreated/ not boiled & 28 & \\
\hline 3 & Drinking water storage & Dispenser & 67 & \\
& & Caldron/teapot & 1 & \\
& & Jug & 4 & \\
& & Pot/sauce pan & 1 & \\
& & Murky/turbid & 3 & \\
\hline 4 & Drinking water quality & Taste & & \\
& & &
\end{tabular}


The following table is the result of water quality inspection from all visited refill depots. The 42 samples examined, 23 depots were declared to be 'contaminated' with water products at a large amount of contamination of average 6,087 $(0 \leq \mu \geq 38) \mathrm{MPN} / 100 \mathrm{ml}$ and 297,420 $(30 \leq \mu \geq 2330.67) \mathrm{CFU} / \mathrm{ml}$. This indicates that the quality of refill drinking water was not allowed for consumption based on WHO recommendation which states that good drinking water is having 0 values on each of MPN or TPC examination.

Table 3 Results of MPN and TPC inspection on refilling water depots

\begin{tabular}{llll}
\hline Number of Depots & Category & Mean MPN (MPN/100ml) & Mean TPC $(\mathrm{CFU} / \mathrm{ml})$ \\
\hline 19 & Clean & 0 & 0 \\
23 & Contaminated & $6.087(0 \leq \mu \geq 38)$ & $297.420(30 \leq \mu \geq 2330.67)$ \\
\hline
\end{tabular}

The distribution of cases and the presence of refilling water depots in the city of Pagatan have a corresponding concentration in which the patient was most likely close to the location of the refill drinking water providers. The proximity of this location determines the accessibility of the urban community so they prefer to use water refills as their primary drinking water source. Figure 1 shows that the refill drinking water depot is spread evenly in the residential area of Pagatan City and is very close to the patient.

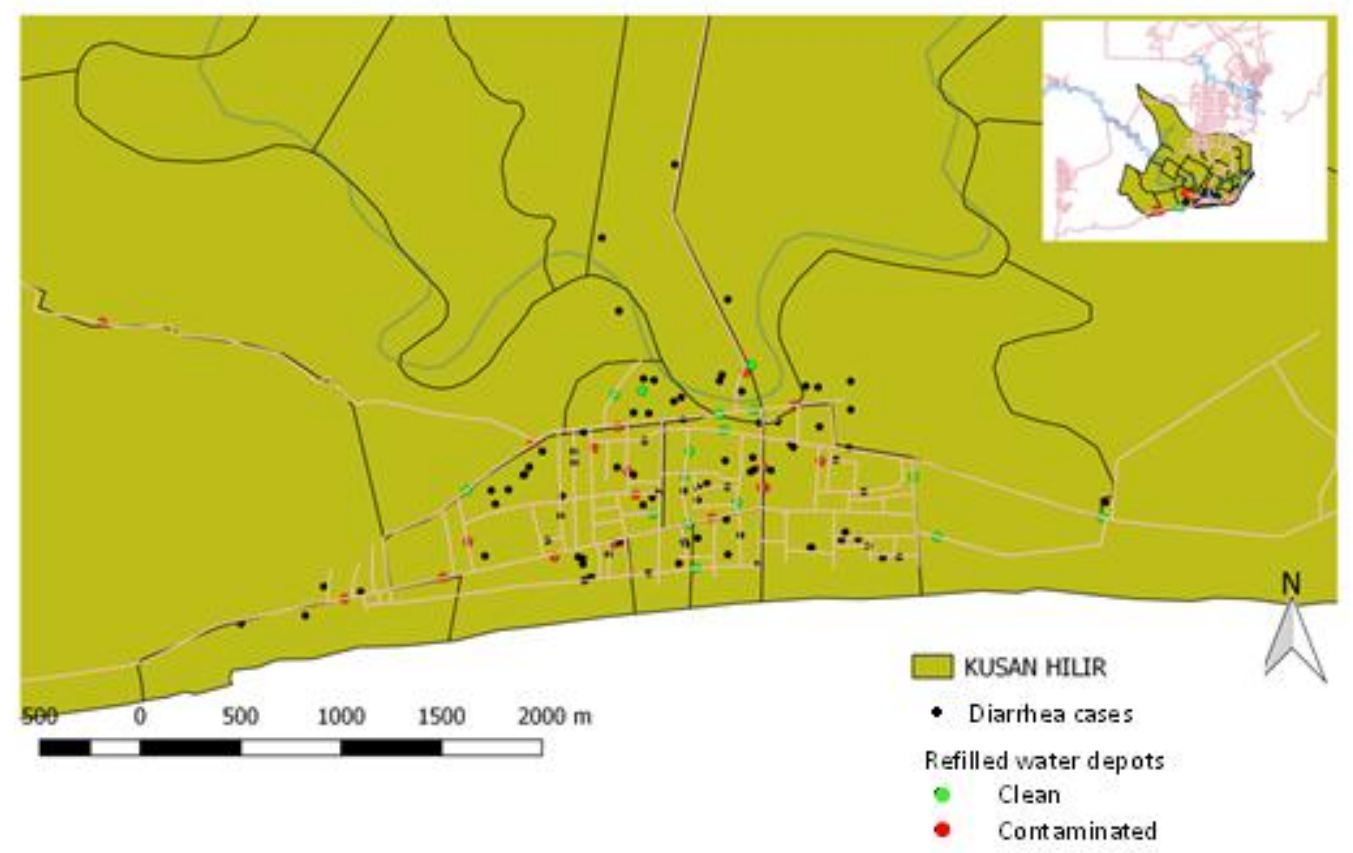

Figure 2 Distribution of refilling water depots and diarrhea cases

The scoring of effect status (figure 3) shows that there are several villages or id locations that have high effect status especially Batuah, Kota Pagatan, Pasar Baru, and Wiritasi located in the center of Pagatan area while some villages on the suburbs of Pagatan such as Mudalang, Muara Pagatan, Sei Lembu, Baru Gelang, Betung and Beringin have medium effect status and some are low. Heatmap is used to facilitate cluster identification where there was high risk concentration so that it becomes the influence for the surrounding exposure. 
Dicky Andiarsa et al / Spatial Effect Of Refilling Drinking Water......

\begin{tabular}{|l|c|c|c|}
\hline \multicolumn{1}{|c|}{ ID Location } & Cases & $\begin{array}{c}\text { Contaminated } \\
\text { Depots }\end{array}$ & Effect Status \\
\hline Batuah & 19 & $86 \%$ & 9 \\
\hline Muara Pagatan & 1 & $100 \%$ & 5 \\
\hline Muara pagatan tengah & 1 & $0 \%$ & 1 \\
\hline Tanete & 4 & $0 \%$ & 1 \\
\hline Wiritasi & 8 & $100 \%$ & 6 \\
\hline Kota Pagatan & 20 & $67 \%$ & 8 \\
\hline Mudalang & 2 & $100 \%$ & 5 \\
\hline Juku Eja & 5 & $0 \%$ & 1 \\
\hline Pasar Baru & 12 & $14 \%$ & 7 \\
\hline Kampung Baru & 1 & $0 \%$ & 1 \\
\hline Pagar Ruyung & 6 & $0 \%$ & 2 \\
\hline Manurung & 4 & $0 \%$ & 1 \\
\hline Gusunge & 4 & $0 \%$ & 1 \\
\hline Pejala & 4 & $100 \%$ & 1 \\
\hline Sei lembu & 2 & $100 \%$ & 5 \\
\hline Pulau Satu & 4 & $0 \%$ & 1 \\
\hline Baru Gelang & 2 & $100 \%$ & 5 \\
\hline Betung & 0 & $100 \%$ & 5 \\
\hline Beringin & 0 & & 5 \\
\hline
\end{tabular}

Figure 3 Heatmap of effect status based on id location

Figure 4 below explains that the concentrations of 'contaminated' depots were at the center of Pagatan City and some other suburbs. There is a correspondence between the density of the depots' position and the density of the diarrheal cases found. This figure shows 'contaminated' depot hotspot having an impact of up to 500 meter radius toward diarrhea patient with a characteristic access to drinking water that has been described.

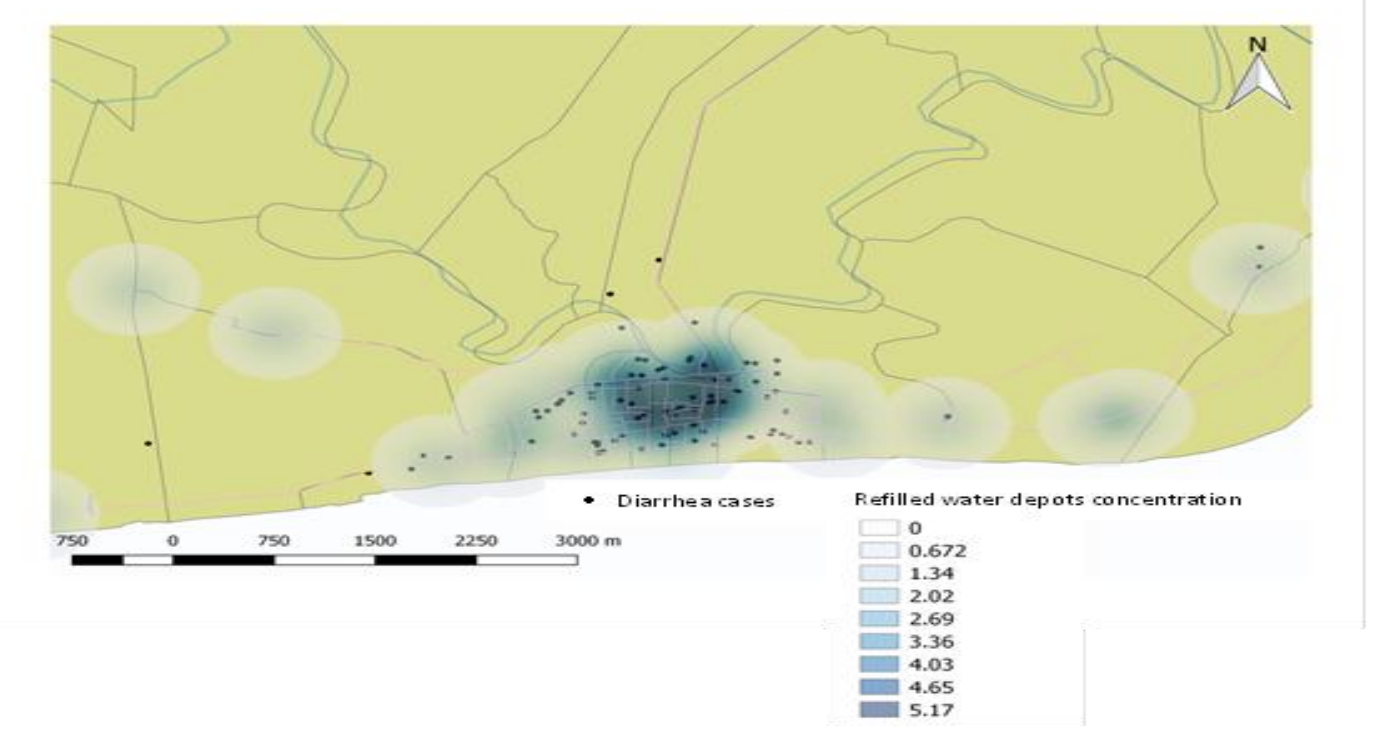

Figure 4: Heatmaps of 'contaminated' depots and diarrhea cases

\section{Discussion}

The results clearly indicate a significant spatial relationship between cases of diarrhea with the presence of refill drinking water depots in the City of Pagatan. Pagatan community was one of urban communities which was 
always have a tendency in choosing the practicality in meeting their needs, including in access to drinking water. Refill depots have proven to change the pattern of Pagatan community's drinking water access behavior by providing convenience and affordable prices in obtaining drinking water in a practical way. The data shows that most respondents choose refilling drinking water as their drinking water even most of them directly drink the water without processing first. The contrast is shown in research in Jakarta which was refilling water users were more at no risk of diarrhea.(Sima et al., 2012)

In Indonesia, refilling drinking water is the third largest source of drinking water used by the community with a percentage of $17.2 \%$.(Kemenkes, 2011; Wandrivel, Suharti and Lestari, 2012)This drinking water refill business has expanded widely and become a source of income for depot entrepreneurs and become a necessity for consumers.(Bayer, 2013)This condition created new characteristics for the community behavior in terms of the ability to seek access to drinking water was easier and cheaper. Government regulation has arranged related to this refilling drinking water business to accommodate the needs of the community, such as maintaining the quality and safety of drinking water products, sanitation inspection, and standard operating procedures of the provision of refillingwater.(Indonesian Ministry of Health, 2014)However, the implementation in the community was often not in accordance with the directed. In the process of water sampling we witnessed some depots did not have an operational permits and claimed to have never visited the officer for water inspection.

Lack of supervision from health workers is very influential on this business work system and will directly affect the quality of the product. 42 depots examined, 23 of depots' water product claimed to be 'contaminated' with high levels of contamination (mean 6,087 $(0 \leq \mu \geq 38) \mathrm{MPN} / 100 \mathrm{ml}$ and 297,420 $(30 \leq \mu \geq 2330.67) \mathrm{CFU} / \mathrm{ml}$ ). This was not in accordance with government regulations that do not allowed drinking water contaminated with E.coli or Coliform at all.(Indonesian Ministry of Health, 2010)

Pagatan city is one of the most densely populated cities in Tanah Bumbu and the capital city for Kusan Hilir sub district. Increasing population growth every year seems to trigger the growth of this refill depot business. Increasing the need for drinking water is not accompanied by an increase in efforts to maintain the quality of drinking water product by doing according to the procedure. Several depots were found serving by delivered drinking water using plastic jerry cans and then transferred to consumers' gallon without have to wash the gallon first. Some depots also did not have the equipment to wash gallons and there were moss grew inside of the gallon of the seller's inventory that would normally be exchanged for the consumer's gallon. This has become a normal sight in the drinking water refill business in the region.

By the distribution of cases, we overlay with a heatmap 'contaminated' depot in the Pagatan area. At a radius of 500 meters from a 'contaminated' depot is an area of impact for the user community around the depot. It can be seen that the densest cluster of diarrhea cases was at the centre of the Pagatan area (Batuah, Pasar Baru, Kota Pagatan and Wiritasi) as well as the corresponding density of the 'contaminated' depots in the same area. This area is the center of economic activities of Pagatan city where in this area there are traditional markets, fish market and most shops and densely populated settlements are also concentrated in this area. Most depots were also found to be close to sources of contaminants such as markets, sewers, landfills, rivers, slums and so on. Some of these factors become one of the determinants of hygiene and sanitation in business in the region. (Sulistyandari, 2009; Puspitasari, 2018)Scores of effect status and heatmap indicate that there is a significant spatial influence of 'contaminated' depots on the occurrence of diarrheal cases in the Pagatan area.

This refilling drinking water business is considered very helpful if reflected from the side of the economy and accessibility to improve the welfare of the community.(Sima and Elimelech, 2013) It will be even more valuable if compensated by consistent quality control of this business product. The regulation properly implemented, good equipment and maintenance operations, sanitary hygiene of the place of business, and good personal hygiene from the handlers (Rahmitha, Utami and Sitohang, 2018) would be able to contribute well to the quality of products provided to the community. However boiling water before drinking may reduce the risk of diarrhea in the community.(Hairani et al., 2017) 


\section{Conclusion}

There is a spatial correlation between the density of the refill depots and the distribution of the diarrheal cases found. The concentration of 'contaminated' depot has a significant effect on the characteristic profile of the majority patients which were being around in the area of the depot.

\section{Recommendation}

- For refilled water provider: standard procedure to operate the refilled water machine should be done, use improved water source, good maintenance of entire machine routinely, good personal hygiene of handlers and change the filter regularly.

- $\quad$ For consumer: water should be boiled before consume and clean up the water dispenser regularly.

- For government: local regulations on refilled drinking water management need to be applied properly.

\section{Author Contribution}

DA design concept of analysis, design study, perform spatial analysis, writing manuscript; DES, IS and SH perform analysis and writing manuscript; $\mathrm{EH}$ and $\mathrm{H}$ prepare equipment and assist technical activities in the field.

\section{Acknowledgement}

Thank you for Head of District Health Office of Tanah Bumbu and Head of Pagat an Local Health Service for technical assistance and data provision so that this study can be done. Thanks to Head of National Agency on Health R\&D Tanah Bumbu for the support of facilities and funds so that this activity can be done. As well as the respondents and owners of the depots who were willing to participate in this study, their valuable information helps to improve policy and its implementation.

\section{References}

Andiarsa, D., Setianingsih, I., Setyaningtyas, D. E., Hidayat, S., Sulasmi, S., Meliyanie, G., Fadilly, A., Hariati, E. and Arianti, D. C. (2016) Analisis faktor penyebab diare di Kabupaten Tanah Bumbu dengan pendekatan Geographical Information System (GIS). (Report). Batulicin.

Andiarsa, D., Setianingsih, I. and Sulasmi, S. (2017) 'Kebijakan pengendalian diare berdasarkan analisis spasial faktor penyebab diare di Kabupaten Tanah Bumbu', Jurnal Kebijakan Pembangunan, 12(1), pp. 9-21.

Bayer, R. (2013) Drinking water as a source of income. Lund University.

Hairani, B., Andiarsa, D., Suriani and Juhairiyah (2017) 'Correlation among mother' s knowledge and practice of boiling drinking water to the incidences of toddler diarrhea in Puskesmas Baringin Kabupaten Tapin year 2014', Journal of Health Epidemiology and Communicable Diseases, 3(1), pp. 10-14.

Indonesian Ministry of Health (2010) Ministry of Health Regulation Number 492 Year 2010 about Concerning the Quality of Drinking Water.

Indonesian Ministry of Health (2014) Ministry of Health Regulation Number 43 Year 2014 about Sanitation Hygiene Dinking Water Depot. Indonesia.

Kemenkes (2011) Basic Health Research (RISKESDAS) 2010 (Report). Jakarta.

Kuswandi (2017) 'Vice Gorvernor of South Kalimantan apreciated the achievement of the development of Tanah Bumbu', Merdeka.Com, April. Available at: https://tanahbumbu.merdeka.com/info-tanahbumbu/wagubkalsel-apresiasi-keberhasilan-pembangunan-tanbu-1704105.html.

Pagatan City Health Service (2016) Diarrhea case register 2013-2015. Pagatan City. 
Puspitasari, E. K. A. (2018) 'Analysis of the factors affecting the quality of the chemical and microbiological drinking water at the depot drinking water refill Tulungagung District', Journal for Quality in Public Health, 1(1), pp. 104-112.

Rahmitha, A., Utami, E. S. and Sitohang, M. Y. (2018) 'Implementation of Geographical Information System for Bacteriological Contamination Analysis on Refill Drinking Water Depot (Study in Tembalang District)', in ICENIS 2017. EDP Sciences, pp. 1-5.

Rumondor, P. P., Porotu'o, J. and Waworuntu, O. (2014) 'Identifikasi bakteri pada depot air minum isi ulang di Kota Manado', e-Biomedik, 2(2), pp. 1-4.

Sima, L. C., Desai, M. M., McCarty, K. M. and Elimelech, M. (2012) 'Relationship between use of water from community-scale water treatment refill kiosks and childhood diarrhea in Jakarta.', The American journal of tropical medicine and hygiene, 87(6), pp. 979-84. doi: 10.4269/ajtmh.2012.12-0224.

Sima, L. C. and Elimelech, M. (2013) 'More than a drop in the bucket: Decentralized membrane-based drinking water refill stations in southeast Asia', Environmental Science and Technology, 47(14), pp. 7580-7588. doi: $10.1021 /$ es304384n.

Sulistyandari, H. (2009) Faktor-faktor yang berhubungan dengan kontaminasi deterjen pada air minum isi ulang di depot air minum isi ulang (DAMIU) di Kabupaten Kendal. Diponegoro University.

Wandrivel, R., Suharti, N. and Lestari, Y. (2012) 'Kualitas air minum yang diproduksi depot air minum isi ulang di Kecamatan Bungus Padang berdasarkan persyaratan mikrobiologi', Jurnal Kesehatan Andalas, 1(3), pp. 129-133. 